\title{
DILEMAS DE UM PROFESSOR NA BUSCA DE UM ENSINO REFLEXIVO
}

\author{
JosÉ LUIZ ZANELLA ${ }^{1}$
}

RESUMO: O texto apresenta uma experiência de docência do autor, realizada no ano de 1999, no Ensino Médio de uma escola pública, após ter concluído o mestrado em educação. 0 objetivo do texto é fazer alguns apontamentos críticos sobre a referida experiência, que expressa os dilemas do docente sobre os conhecimentos adquiridos no mestrado e as contradições da prática educativa no âmbito da sala de aula. A partir da perspectiva da filosofia da práxis, posiciona-se criticamente em relação ao ensino reflexivo.

Palavras-chave: Filosofia da práxis. Ensino reflexivo. Docência.

\section{TEACHER CLASSROOM DILEMMAS IN SEARCH OF A REFLEXIVE TEACHING}

ABSTRACT: The paper presents the author's teaching experience in a public school in High School. The teaching was done in 1999 after the author's Master conclusion. The aim of the paper is to make critical appointments about such experience, expressing the teacher dilemmas about the knowledge acquire in master degree and the contradictions of educational practice within the classroom. From the perspective of praxis philosophy, the paper stands critically against reflexive teaching.

Keywords: Praxis philosophy. Reflexive teaching. Teaching.

\section{DILEMAS DE UN PROFESOR EN LA BÚSQUEDA DE UNA ENSENÃNZA REFLEXIVA}

RESUMEN: Este texto presenta una experiencia de docencia del autor, celebrada en 1999, en la educación secundaria de una escuela pública, después de completar una maestría en educación. El propósito del documento es hacer algunas notas críticas de esa experiencia, que expresa los dilemas del docente con respecto a los conocimientos adquiridos en la maestría y las contradicciones de la práctica educativa en el aula. Desde la perspectiva de la filosofía de la praxis, se posiciona críticamente con relación a la enseñanza reflexiva.

Palabras clave: Filosofía de la práxis. Enseñanza reflexiva. Docencia.

\section{Introdução}

Este texto tem por objetivo apresentar e analisar a experiência de docência vivida junto a duas turmas de primeiro ano do Ensino Médio, na disciplina de Psicologia, no ano de 1999, quando concluí o mestrado em educação e retomei a docência no Colégio Estadual de Dois Vizinhos, PR. Trata-se de uma

\footnotetext{
${ }^{1}$ Doutor em Educação. Docente da Universidade Estadual do Oeste do Paraná - UNIOESTE, Francisco Beltrão. zanellazl@hotmail.com.
} 
reflexão sobre a tentativa de colocar em prática algumas contribuições-que tinha adquirido no mestrado sobre a teoria do ensino reflexivo ${ }^{2}$. Sabia que essa teoria se fundamentava no pragmatismo de Dewey, mas eu buscava, pela práxis educativa, incorporar, por superação dialética, algumas daquelas contribuições do ensino reflexivo para uma perspectiva da filosofia da práxis (GRAMSCI, 1999) e da Pedagogia Histórico-Crítica (SAVIANI, 1997, 2003).

Decorridos dezessete anos daquela experiência que ora apresento, evidencio que, naquele momento, não encontrava respostas na Pedagogia Histórico-Crítica para trabalhar com a "dimensão artística" do trabalho educativo em relação à "dimensão técnica", que, posteriormente, foi assim formulada por Saviani.

A técnica é definida como a maneira considerada correta de se executar uma tarefa. Como tal, ela se caracteriza por um conjunto de regras extrínsecas que são compendiadas tornando-se suscetíveis de serem apropriadas e aplicadas na atividade prática. Implica, pois, em repetitividade. A arte, por sua vez, também se refere à realização prática. Entretanto, diferentemente da técnica, ela se define por regras intrínsecas, ditadas pela própria obra a ser feita. Implica, pois, em originalidade. Ora, no campo da educação nós encontramos ambas as dimensões. Pela dimensão técnica, é possível extrair dos enunciados e princípios da teoria da educação determinadas regras que devem ser seguidas na realização do ato educativo. Essa é a forma que se manifesta na composição dos programas escolares das diversas disciplinas nos quais se definem os objetivos a serem atingidos, os conteúdos a serem estudados e os procedimentos que serão adotados nas aulas dia a dia, semana a semana, mês a mês, ao logo de todo o período letivo a fim de viabilizar o estudo dos conteúdos e, assim, atingir os objetivos que justificam o ensino daquela disciplina. No entanto, o trabalho educativo, além da dimensão técnica, contém, também, uma dimensão artística. Ou seja, a obra educativa se reveste de um alto grau de originalidade que dita ao educador determinadas regras de caráter intrínseco que, portanto, não são suscetíveis de serem compendiadas externamente para sua aplicação mecânica na realização prática da tarefa educativa. Esse aspecto artístico que em condições normais convive com o aspecto técnico exigindo do professor que encontre a medida adequada de combinação das regras intrínsecas e extrínsecas na realização de sua tarefa, em determinados momentos pode se manifestar de forma mais saliente (SAVIANI, 2011, p. 204-205).

Hoje, essa argumentação de Saviani me explica a razão de ter buscado trabalhar com a dimensão artística da teoria do ensino reflexivo, porque era o que me situava em relação a compreender as "regras de caráter intrínseco" do trabalho docente.

\footnotetext{
2 Utilizarei a denominação teoria do ensino reflexivo referindo-me à vertente americana.
} 
Na primeira parte do texto, apresento "minha" filosofia da educação, enquanto posicionamento teórico-metodológico que, a partir de determinada problemática no ensino, busca incorporar algumas contribuições da teoria do ensino reflexivo. Na segunda parte, apresento as observações e registros das aulas realizadas durante o ano. Estão aí expostos os dilemas e as limitações do docente diante do comportamento dos alunos em sala de aula, quando lhes é oferecida uma proposta de ensino que os toma como sujeitos para que construam, a partir do diálogo reflexivo, a autonomia moral e a autodisciplina intelectual. O texto é finalizado com alguns apontamentos críticos em relação à teoria do ensino reflexivo, com os quais também estabeleço autocrítica, fundamentado no conceito de "trabalho educativo", de Saviani (2003)

\section{A “Minha” Filosofia da Educação}

Desde quando iniciei no magistério, em 1990, passando por todos os níveis de ensino, verifiquei que tinha dificuldades de estabelecer um vínculo orgânico e de práxis entre o que pensava e o que realmente fazia. Isso não significava que o meu modo de ensinar fosse totalmente expositivo, metafísico, autoritário, espontaneísta e tecnicista. O fato é que, apesar dos esforços para que os alunos participassem, meu trabalho se centralizava na transmissão de conteúdos, sem uma consistente reflexão sobre o mundo dos alunos, para superação do senso comum e encaminhamento à consciência filosófica. A questão de como relacionar os conhecimentos dos alunos (senso comum, bom senso) com os conhecimentos escolares (ciências, filosofia, cultura) num processo reflexivo, a partir dos alunos, permanecia em aberto e se constituía em um problema que me angustiava, principalmente porque partia do pressuposto de que

\footnotetext{
[...] todo homem, fora de sua profissão, desenvolve uma atividade intelectual qualquer, ou seja, é um 'filósofo', um artista, um homem de gosto, participa de uma concepção de mundo, possui uma linha consciente de conduta moral, contribui assim para manter ou para modificar uma concepção de mundo, isto é, para promover novas maneiras de pensar (GRAMSCI, 1991, p. 7-8).
}

Com tal fundamento, pensava em fazer no ensino o movimento de modificação da concepção de mundo, tendo como princípio que todos os alunos são ativos e desenvolvem uma atividade intelectual. Se os alunos não aprendem, pensava, é possível que o problema esteja na minha metodologia de ensino.

Foi o problema da metodologia de ensino que me levou ao mestrado em educação. Buscava aprofundar os estudos na perspectiva da Pedagogia Histórico-Crítica (SAVIANI, 1997, 2003). No entanto, 
ao cursar o mestrado, os estudos sobre a teoria do ensino reflexivo pareceram-me o novo que tanto procurava, ou seja, como fazer para resolver os problemas decorrentes no processo de ensino. Somente após a qualificação da dissertação me dei conta de que a perspectiva do ensino reflexivo estava fundamentada no pragmatismo de Dewey. Mesmo assim, pensava em fazer uma incorporação por superação de algumas contribuições dessa teoria, na perspectiva da Pedagogia Histórico-Crítica. Mas o queria fazer a partir de uma experiência educativa. A seguir, apresento brevemente alguns conceitos da teoria do ensino reflexivo que tomei como referência para minha experiência.

A teoria do ensino reflexivo, nascida a partir da segunda metade do século passado, faz a crítica à racionalidade técnica. A "racionalidade técnica" entendida como um conjunto de conhecimentos considerados como de certo modo verdadeiros sobre as ciências da educação e do como ensinar, adquiridos nas universidades, que os professores aplicariam na prática sem se preocuparem com o contexto, mas apenas atendo-se aos objetivos previamente estabelecidos. A crítica a essa concepção de ensino é feita por autores como Nóvoa (1995), Schön (1995), Zeichner (1993), dentre outros, sobretudo com fundamentos em Aristóteles, Dewey e Habermas.

Na prática educativa, a racionalidade técnica é substituída pela racionalidade prática e assim explicitada: "na prática não existem problemas, mas sim situações problemáticas, que se apresentam frequentemente como casos únicos que não se enquadram nas categorias genéricas, identificadas pela técnica e pela teoria existentes" (GOMES, 1995, p. 100).

Nessa perspectiva, a sala de aula é vista e compreendida como um espaço complexo, incerto e imprevisível. Espaço que, por ser assim, exige um professor "como prático autônomo, como artista que reflete, que toma decisões e que cria durante a sua própria ação" (GOMES, 1995, p. 96).

Valoriza-se, sobretudo, a experiência pessoal do professor.

O conceito de professor como prático reflexivo reconhece a riqueza da experiência que reside na prática dos bons professores. Na perspectiva de cada professor, significa que o processo de compreensão e melhoria de seu ensino deve começar pela reflexão sobre a sua própria experiência e que o tipo de saber inteiramente tirado da experiência dos outros (mesmo de outros professores) é, no melhor dos casos, pobre, e na pior, uma ilusão (ZEICHNER, 1993, p. 17, grifos meus).

Nos EUA, o movimento do ensino reflexivo tem seu referencial no filósofo liberal John Dewey (1953), para quem o "pensamento reflexivo" se fundamenta no exame ou averiguação, entre as ideias e 
os fatos. Significa que toda a reflexão tem como base a experiência pessoal, a qual é tomada com "perplexidade", "confusão" ou "dúvida".

\footnotetext{
Dewey definiu a ação reflexiva como sendo uma ação que implica uma consideração ativa, persistente e cuidadosa daquilo em que se acredita ou que se pratica, à luz dos motivos que justificam e das consequências a que conduz [...]. Reflexão é uma maneira de encarar e responder aos problemas, uma maneira de ser professor [...]. A reflexão implica intuição, emoção e paixão; não é, portanto, nenhum conjunto de técnicas que possa ser empacotado e ensinado aos professores (ZEICHNER, 1993, p.18).
}

Portanto, para Dewey, onde há reflexão há incerteza, e a postura reflexiva requer três atitudes: a) abertura de espírito - ouvir os outros, estar aberto às alternativas e admitir seus próprios erros; b) responsabilidade - busca dos fins éticos e políticos das ações; c) sinceridade - capacidade de indignação, adesão e entusiasmo pelo que se faz. Schön (1995), ao retomar Dewey, desenvolve o que denominou de uma praxiologia para a reflexão. Utilizou conceitos como: "conhecimento na ação" - valorização do próprio conhecimento; "reflexão na ação" - diálogo reflexivo no momento da ação; "reflexão sobre a ação" retomada e reconstrução mental da reflexão na ação para análises; e "reflexão sobre a reflexão na ação" - progressão continuada do profissional de forma pessoal.

Quando concluí o mestrado, em 1999, tinha clareza dos pressupostos liberais e pragmáticos da teoria do ensino reflexivo. Mas, ao mesmo tempo, entendia que, na perspectiva dialética, poderia incorporar as contribuições acima apresentadas, a partir dos pressupostos da filosofia da práxis (GRAMSCl, 1999, 2000). Por exemplo, incorporei, da teoria do ensino reflexivo, contribuições à "dimensão artística" do processo ensino-aprendizagem.

Foi assim que, além dos apontamentos citados sobre o ensino reflexivo, fundamentei o trabalho em valores do humanismo gramsciano da "autodisciplina intelectual e autonomia moral" (MANACORDA, 1990, p. 161). Em sua concepção de escola unitária - entrelaçamento entre trabalho manual e trabalho intelectual - Gramsci distingue duas fases na educação das crianças. Na primeira fase, antes da puberdade, até aos 14 anos, a educação se centra na formação da personalidade e vai desenvolver por meio de um ensino receptivo, dogmático e de heteronomia, o hábito e disciplina necessários ao estudo - fase da "pedagogia da exigência". Contudo, o autor adverte, "a aquisição dos hábitos de disciplina e todo o estímulo exercido sobre a criança pelos adultos devem, todavia, ocorrer 'sem mortificar a espontaneidade da criança'" (GRAMSCI apud MANACORDA 1990, p. 91). 
Na segunda fase, após a crise da puberdade, a educação passa da heteronomia para a autonomia. É a fase "criativa", ou seja, da "autodisciplina intelectual e da autonomia moral". Nessa etapa, os jovens devem ser capazes de estudar várias horas por dia, de forma organizada e planejada, tendo em vista seus projetos de vida, sempre numa perspectiva de classe social (visão de mundo unitária e coerente).

Tendo como base esses pressupostos, entendia que os alunos do primeiro ano do colegial já tivessem, de certa forma, adquirido o hábito de estudo por uma opção de projeto de vida e não só por ser uma exigência dos pais, da sociedade, dos professores e da escola. Assim, meu objetivo era proporcionar um ambiente em sala de aula livre de todos os "vícios" tradicionais da escolarização, tais como: o estudo pela nota, autoritarismo, punições, perseguições etc. Livre desses entraves da escolarização, queria que os alunos pudessem dizer a sua palavra com liberdade de expressão e pensamento, sem medo e constrangimentos de punições ou advertências. Deixei claro que os alunos poderiam se manifestar sempre da meIhor forma que pudessem. Por exemplo, poderiam dizer: professor, tua aula não está com nada, foi chata etc.; também, tinha clareza de que esse enfoque não saía do autoritarismo e podia cair no outro extremo - o do espontaneísmo.

Buscava, mediante a prática do diálogo reflexivo, consolidar nos alunos um comportamento (hábito) de responsabilidade (autonomia) diante dos estudos, no sentido de que fossem capazes de resolver as contradições do próprio estudo e de convivência em sala de aula, a partir da explicitação de suas contradições, à medida que estas surgissem na aula. Ou seja, queria que os alunos enfrentassem as tensões, que, à medida que elas surgissem, fossem capazes de parar, avaliar, esclarecer e tirar encaminhamentos consensuais. O papel do professor consistia em insistir na reflexão, fornecendo elementos, fazendo mediações, para que eles, os alunos, refletissem de forma coletiva e democrática.

Considerava como meta o cultivo de valores (vivência/convivência) como o respeito, o autoconhecimento, a abertura para o outro, a liberdade, a responsabilidade, o exercício da cidadania ativa, a solidariedade, a democracia, a busca da sabedoria e, principalmente, o diálogo reflexivo, crítico e autocrítico. Enfim, minha filosofia de trabalho se fundamentava no materialismo histórico dialético, no sentido de que realizava as reflexões a partir das explicitações dos determinantes sociais. Dessa forma, buscava enfocar dialeticamente os conceitos de "ensino reflexivo", já que eles estavam envoltos numa concepção de mundo não marxista, para incorporá-los de forma mais contextualizada e de práxis crítica.

Entendo que a concepção da práxis marxista é mais elevada que a concepção de práxis aristotélica, fins éticos e políticos, e da prática de Dewey, o pragmatismo. 
A práxis é a atividade concreta pela qual os sujeitos humanos se afirmam no mundo, modificando a realidade objetiva e, para poderem alterá-la, transformando-se a si mesmos. É a ação que, para se aprofundar de maneira mais consequente, precisa da reflexão, do autoquestionamento, da teoria: e é a teoria que remete à ação, que enfrenta o desafio de verificar os seus acertos e desacertos, cotejando-os com a prática (KONDER, 1992, p. 185).

Procurei enfocar, desse modo, a reflexão no ensino a partir do "concreto" como síntese de múltiplas determinações, da "totalidade" como um todo que se cria e se transforma, e da "dialética", reflexão a partir das contradições.

Esse enfoque de reflexão no ensino se deu a partir do mundo do trabalho. Explicitando o trabalho alienado e, ao mesmo tempo, desvelando que somos uma "classe social" que vive do trabalho e como tal temos uma história de lutas no sentido de transformação das relações de trabalho da atual sociedade. Buscava construir nos alunos uma visão de mundo coerente com seu lugar social. Assim, queria que os alunos fossem capazes de elaborar "a própria concepção de mundo de uma maneira crítica e consciente [...] escolher a própria esfera de atividade, participar ativamente na produção da história do mundo" (GRAMSCl, 1990, p. 12).

\section{As Aulas}

Tendo como base esses apontamentos e algumas outras leituras sobre o ensino reflexivo, assumi o desafio de ser, de fato, um professor reflexivo em sala de aula. Esse desafio teria que ser durante o ano todo e nas mesmas condições de trabalho dos outros professores - mesma carga horária e de estrutura de funcionamento do colégio.

Retomei minhas atividades de professor da rede estadual em fevereiro de 1999, com as seguintes condições de trabalho: no colégio, 20 horas semanais, distribuídas entre o período da manhã e tarde. Disciplinas no período da tarde: História, 8a D (duas aulas), 1ㅇ C (duas aulas) e 1으 D (duas aulas). Disciplinas no período da manhã: História, 1ㅇ A (duas aulas), 1ㅇ B (duas aulas), 2 A (duas aulas), 2ㅇ B (duas aulas) e 2ㅇ C (duas aulas). Psicologia, 1ㅇ A (duas aulas) e 1ㅇ B (duas aulas). As aulas tinham duração de 45 minutos. Os alunos não possuíam material didático (livros, textos etc.) nem tinham condições de adquiri-los.

Essa jornada de trabalho no colégio se complementava com a da universidade, como professor celetista/contratado, com mais 26 horas semanais, assim distribuídas: 
- 10 horas de extensão - trabalhava em dois dias por semana na coordenação do "Projeto Vida na Roça" junto a uma comunidade de agricultores familiares;

- 10 ano de Pedagogia Educação Infantil - Filosofia da Educação, 4 aulas;

- $1^{\circ}$ ano de Pedagogia Séries Iniciais do Ensino Fundamental - Filosofia da Educação, 4 aulas;

- 20 ano de Pedagogia Educação Infantil - Filosofia da Educação Brasileira - 3 aulas;

- 20 ano de Pedagogia Séries Iniciais do Ensino Fundamental - Filosofia da Educação Brasileira, 3 aulas; e

- $\quad 10$ ano de Ciências Econômicas, com a disciplina Noções de Ciências Sociais, 2 aulas.

Ressalte-se que a universidade, localizada na cidade de Francisco Beltrão-PR, estava a 50 km de onde residia, implicava duas horas diárias de viagem entre ida e volta. Diante da extensa jornada de trabalho e de condições de trabalho desfavoráveis ao estudo e reflexão, delimitei a minha proposta para ser um professor reflexivo com mais intensidade no 1으 $\mathrm{A}$ e no 1 으 $\mathrm{B}$ da manhã nas aulas de Psicologia, no Ensino Médio (Colégio). A delimitação se impôs pela falta de tempo que tínhamos para fazer os registros das aulas. No entanto, a escolha de Psicologia foi estratégica, uma vez que a direção do colégio a incluiu no currículo na tentativa de resolver a agressividade e indisciplina dos alunos.

Em linhas gerais, essas duas turmas se caracterizavam por serem adolescentes com idade entre 14 e 16 anos, divididos quanto ao gênero quase que proporcionalmente em mesmo número entre meninos e meninas. Cada sala de aula tinha em torno de 40 alunos. Em relação ao trabalho dos pais, poderíamos classificar deste modo: em torno 6\% microempresários e o restante, assalariados (mecânicos, vendedores, capatazes de fazenda, motoristas, viajantes, vigilantes, agricultores familiares, operários, técnicos, desempregados, aposentados). A maioria das mães trabalhava em casa e, quando fora de casa, como assalariadas. Os filhos, no caso os alunos, auxiliam de alguma forma no trabalho dos pais. As informações sobre o trabalho mostram que todos viviam de seu próprio trabalho e a maioria com renda familiar que apenas garantia a sobrevivência.

Ao iniciar as aulas, solicitei aos alunos que, de um ponto de vista existencial, indicassem o que mais os preocupava para que isto fosse objeto de estudos em Psicologia. A maioria dos assuntos convergiu para a sexualidade. Foi assim que, no mês de março, iniciamos estudando a Psicanálise. Como professor, entendia que, se apresentasse alguns dos principais conceitos da psicanálise, os alunos poderiam refletir com maior conhecimento de causa sobre suas angústias sexuais e comportamentos agressivos.

A metodologia, nesse mês, foi de certa forma "tradicional". O professor chegava à sala de aula e 
apresentava os conceitos, escrevendo-os no quadro ou ditando aos alunos, visto que eles não tinham condições de adquirir um texto. A aula era praticamente expositiva. Iniciava-se por uma revisão breve da aula anterior e, por meio de um "diálogo dirigido", apresentavam-se os novos conceitos.

Por que essa metodologia, se o objetivo era um ensino reflexivo? Na verdade, após alguns dias, numa autoavaliação, cheguei à conclusão que a rotina e a própria tradição do ensino escolar ainda eram determinantes em meu trabalho. Quando me dei conta, percebi a dificuldade que tinha de relacionar de forma orgânica o "conhecimento" problematizado dos alunos com os conceitos da Psicanálise. Verifiquei que estava fazendo uma relação de justaposição, de encaixe, bem aos moldes da "racionalidade técnica". A teoria, os conceitos, era tomada como uma verdade a ser aplicada na prática, no caso, nos alunos. Enfim, era o "pacote" de conhecimentos a serem repassados aos alunos para que eles dessem conta de desempacotar.

A reação dos alunos foi imediata. Como eram livres para se manifestarem, diziam que não compreendiam minhas explicações sobre aqueles conceitos de "id", "ego", "superego" etc. Por mais que me esforçasse, inclusive com o desenho de gráficos e de outros recursos, não conseguia encontrar uma linguagem mais acessível que chegasse aos alunos. Muitos deles reagiram desinteressando-se pelas aulas, formaram-se grupos que faziam outras atividades e muitas conversas paralelas. Muitos escreviam bilhetes que eram deixados discretamente na mesa do professor, dizendo que a aula era chata e que não os interessava.

Diante desse desinteresse dos alunos e de suas reivindicações, realizei, enquanto professor, uma avaliação das aulas e optei por retomar os temas específicos sobre sexualidade apontados pelos alunos no início das aulas. Mudei a metodologia. De início apresentava uma ou duas questões para problematizar o assunto, procurando resgatar ao máximo possível as falas dos alunos, que eram interpretadas e explicadas pelo professor. Completava as reflexões com algumas leituras, geralmente de livros da Martha Suplicy ou de algum outro livro ou revista que os próprios alunos traziam.

Nesse processo de aula reflexiva e coletiva, a confusão, em muitos momentos, tornara-se generalizada e quase impossível de ser controlada. A falação era tanta que tinha muita dificuldade de ser ouvido pelos alunos. Muitos queriam falar ao mesmo tempo e o faziam de forma dogmática, exaltada e instintiva. O ambiente se tornou impróprio ao diálogo: desrespeito, gritos, acusações, indiferença com a aula, pois ela era entendida como "matação" e bagunça e pouco caso ou seriedade com as reflexões. Chegou ao ponto de os conflitos passarem do plano verbal para o da agressão física. Um fato marcante foi a briga a 
socos e pontapés entre dois alunos em sala de aula com o incentivo e desafio da turma. No momento da briga, os alunos insistiram que chamasse a direção, mas, com muita calma contornei a situação e procurei fazer daquele conflito uma reflexão. Porém, diante da gravidade do ocorrido, no intervalo, chamei os dois alunos e os levei até a sala da direção para evitar um confronto maior com consequências imprevisíveis. Foi constrangedor ter de ir até a sala da direção. Lá, foi lavrada a ocorrência no 24/99, ditada pelo diretor e escrita pelo vice-diretor.

Aos vinte e quatro dias do mês de março do ano de mil novecentos e noventa e nove, compareceu o professor José Luiz Zanella, com os alunos x e y do 1 으. $\mathrm{Na}$ aula de Psicologia, onde discutiam o assunto sexualidade, o aluno $x$ em sua colocação ofendeu as alunas da sala referindo-se que as mesmas por saírem acompanhadas seriam meninas de "vida fácil", prontamente o aluno y colocou que o $\mathrm{x}$ foi visto em companhia de dois homens, da mesma maneira incriminado suspeita sobre a masculinidade do mesmo. O que ocasionou um desequilíbrio e posteriormente violenta agressão física ao aluno x que não esboçou nenhuma reação. Data a gravidade do fato, o aluno y foi suspenso pelo período de 3 (três) dias. 0 aluno y fica advertido e na reincidência serão aplicadas as normas contidas no regimento escolar (assinam o professor, os dois alunos e o diretor).

Fiquei perplexo diante desse fato. Saber que esses alunos se agrediram por causa de minha metodologia de ensino era-me algo confuso. Com dez anos de magistério era a primeira vez que isso acontecia. Senti-me, de certo modo, fracassado. Quase todos os professores que têm problemas com os alunos resolvem-nos na sala da direção (espécie de delegacia para mediação de conflitos). Eu, que havia concluído o mestrado em educação e queria, de certo modo, marcar a diferença na escola, acabava de cair no mesmo lugar. Parecia que todos os meus estudos sobre o ensino reflexivo não faziam diferença, ao contrário, criavam mais problemas, dificuldades e confusões. Refleti: seria tudo isso uma consequência "natural" do ensino reflexivo? Ou eu não estaria ainda suficientemente preparado enquanto professor para tal empreendimento?

Ainda confuso e sem ter bem claro o que fazer, na semana seguinte realizei uma avaliação escrita, espécie de prova, com questões reflexivas sobre os conceitos de Psicanálise estudados e, na última questão, solicitei que os alunos avaliassem seus comportamentos à luz daqueles conceitos. As respostas me surpreenderam. Eis algumas:

\footnotetext{
"O comportamento da sala é muito tumultuado. Com aquele trabalho que o senhor está fazendo, que ocorre a briga, as pessoas estão dizendo o que pensam e muitas não concordam, então, começam a discutir".

"Os alunos estão revelando o que pensavam sem ter medo das consequências. $E$
} 

dos pensarem, não só em si, mas nos outros também, e acima de tudo está faltando respeito".

“O professor tenta impor autoridade na sala, mas os alunos 'mandam' nele, ele não consegue dar aula. Existe nessa sala grupinhos que conversam todas as aulas, não prestam atenção e se acham os máximos. Se acham demais, um quer ser mais que o outro".

"Eu preciso melhorar muito, desculpe professor José Luiz".

"Existem pessoas na sala de aula que são muito esquentados, por qualquer coisa que se fala a pessoa já queima, por isso não dá para por nada em debate, porque acontecem brigas e muitas discussões de desentendimentos entre a turma".

"Nós alunos não sabemos o que é ser bom! Os alunos são bagunceiros demais da conta, se aproveitam de sua dignidade, de sua bondade, eles se aproveitam do professor na fiusa que com professor é bom demais.

Os alunos nunca tiveram espaço dentro da sala de aula para ficar à vontade, agora que eles têm esse poder, não sabem aproveitar nada, nem um sequer o respeito com colega que isso é o mais comum".

"Existem vários grupos de alunos que pensam coisas diferentes, mas não sabem expressar esses pensamentos, provocando várias reações críticas como agressões por palavrões, chegando ao ponto de agressões físicas.

Fora as aulas de Psicologia, o comportamento é bom sem brigas e todo mundo é amigo sem preocupações e nenhum tipo de agressão".

"O comportamento da turma não é correto, e isso acontece em função da separação de grupos, onde cada um tem ideias diferentes e também uns não aceitam as ideias dos outros".

"O comportamento de uns está passando dos limites, pelo meu ver, o professor está oportunidade para se expor suas ideias, mas estão se desrespeitando a ideia dos colegas e até mesmo do professor".

"Estamos na hora de sermos mais conscientes e de parar para uma reflexão".

"Os alunos da sala estão muito bagunceiros, não prestam atenção, não têm respeito um com o outro, muitos apelidos, tiram saro, conversa paralela, enfim, a sala tem muitos problemas, principalmente aluno com aluno, e nós temos que melhorar, porque senão a coisa tá feia e o professor tem que tomar atitudes mais severas, porque eles tão se aproveitando do professor".

“O professor quer mudar, quer ajudar, só que ninguém está entendendo. Eu acho que o professor é uma pessoa que luta e consegue o que quer; por isso eu acho que o professor até o final do ano vai conseguir o que quer".

Essas falas foram muito significativas para o meu trabalho. Copiei, olhei e refleti muito sobre elas. Foi a partir dessas falas que readquiri a esperança de seguir em frente, uma vez que elas sinalizavam algumas problemáticas e apontavam novas possibilidades de superação. Interpretá-las tornou-se um desafio permanente. Apresento, a seguir, algumas de minhas interpretações.

a) Sobre os alunos: reconheceram que havia um espaço em sala de aula para que dissessem o que realmente pensavam sem medo. Porém, ao mesmo tempo, a constatação de não saberem expressar 
seus pensamentos num coletivo (palavrões, agressões físicas); descobriram e tomaram consciência de que tinham um comportamento agressivo, instintivo e de revolta (esquentados, bagunceiros, falta de atenção); viram-se num ambiente livre e democrático que pressupunha a responsabilidade pessoal e, como não estavam habituados, não sabiam o que fazer com toda aquela liberdade; confundiram a proposta democrática do professor com o fato de "ser bom" interpretado por eles no sentido de deixar à vontade, o que, no limite, redundaria numa libertinagem e num democraticismo, patologias da liberdade e da democracia; da dificuldade de compreenderem o que o professor queria; e, por último, constataram o quanto eram divididos enquanto turma. Essa divisão se manifestava claramente nos grupos naturalmente constituídos que não se aceitavam. Eram rivais e se hostilizavam permanentemente.

Ao mesmo tempo, observei que as falas dos alunos indicavam o que estavam necessitando. Vejamos, diziam que faltava construir entre eles a prática do diálogo no sentido de pensarem nos outros e com os outros, ou seja, de levar em conta e de valorizar o que o outro pensava, mesmo que este pensamento fosse diferente do seu, da necessidade do respeito mútuo entre os alunos e dos alunos com o professor; e que, enquanto alunos, necessitavam parar e refletir com maior profundidade sobre seus comportamentos.

Enfim, para mim, essas falas dos alunos, naquele momento, revelavam o que tinha sido a escola na vida deles. Uma instituição que Ihes havia tirado a possibilidade de serem eles mesmos. Na escola, eram educados para serem alguém para os outros, em detrimento de serem eles mesmos. Por isso, o medo, a falta do autoconhecimento e, sobretudo, do respeito com os outros. Todos eles, com mais de dez anos de escolarização, tinham dificuldade de dizerem seus próprios pensamentos, ou seja, não sabiam dialogar num coletivo. Ficava a questão: o que a escola fez com esses alunos e como tomar essa problemática no sentido de superá-la?

b) Quanto ao professor, destacavam com veemência que este era "mandado" e desrespeitado pelos alunos, e que, por esta razão, o professor teria que ser mais severo, autoritário. Para os alunos, o fato de o professor ouvi-los e respeitar as suas falas, significava algo parecido com frouxidão. No meu entender, isso decorria, em parte, pelo fato de eles, enquanto alunos, não se valorizarem enquanto pessoas e muito menos sobre o que tinham a dizer. Assim, quando o professor os ouvia, isto lhes parecia insignificante e irrelevante. Porém, é preciso destacar que esse processo de ouvir os alunos e trabalhar com suas falas em sala de aula, numa situação em que eles não estavam preparados para tal metodologia, ocorria num ambiente extremamente confuso, de múltiplas situações imprevistas, que ultrapassavam as minhas capacidades. As colocações dos alunos eram tão instintivas, inconstantes e carregadas de palavras 
ofensivas, que geravam um ambiente nervoso, tenso e explosivo. Respeitar essas palavras e retomá-las como objeto de reflexão num coletivo, no momento que elas surgiam, era extremamente desafiador. Em muitos momentos não conseguia, enquanto professor, me concentrar e acalmar a turma. Por mais que fossem claras as regras metodológicas do debate, mesmo assim os alunos se comportavam como se elas não existissem. O desrespeito em relação ao professor estava em impedi-lo de falar. Na retomada dos pontos conflitivos, muitos alunos não aceitavam as colocações do professor, interrompendo sua fala com palavras de deboche e indiferença.

E como eu era radical em minha filosofia de trabalho, não utilizei nenhuma imposição de comportamento disciplinado. Ao contrário, queria que aqueles alunos, a partir daquelas situações, construíssem, mediante reflexões, um comportamento próprio que fosse autodisciplinado. Tendo isso presente, concluí que o caminho era esse e que tinha de avançar na prática do diálogo reflexivo enfrentando os obstáculos.

Optei por parar com os estudos sobre a sexualidade para refletir com mais cuidado sobre os comportamentos da turma. Para iniciar esse trabalho, realizei no mês de maio um diagnóstico com a finalidade de conhecer melhor quais eram de fato os problemas, suas causas, se havia vontade de mudança e o que fazer para mudar. Apesar de que essas questões já tivessem de certa forma sido respondidas pelas falas anteriores, queria que os alunos refletissem melhor e, de certo modo, que se tocassem no sentido de se assumirem enquanto sujeitos responsáveis. Esse diagnóstico continha quatro questões para serem respondidas em grupos. Quais são os principais problemas em sala de aula com relação aos alunos e ao professor; Enquanto alunos, queremos mudar esta realidade? Por quê? O que propomos para uma mudança da turma e do professor?

Com esse diagnóstico tivemos - alunos e professor - maior clareza sobre nossas limitações e da necessidade de mudanças. Os alunos compreenderam, em parte, os seus problemas ao relatarem sobre as conversas paralelas, do não interesse de alguns ao estudo, das diferenças e da falta de respeito. Quanto ao professor, o problema maior e que incomodava os alunos era: ser "calmo", falta de "rigidez" (autoridade) e o consequente não "domínio de turma".

Sobre as causas desses problemas, constatei que os alunos tiveram dificuldades em responder, e as respostas expressavam, na maioria dos casos, novamente a citação do problema. Segundo os alunos, as causas de seus problemas estariam na família (falta de diálogo), na supervalorização da amizade restrita a grupos, no desinteresse em aprender e na falta de respeito. Com relação ao professor, as causas desses 
problemas estariam no fato de ser muito calmo, tom de voz inadequado, aula não interessante, e de não ter autoridade. Alguns defenderam que o professor não devia ser autoritário, mas que apenas desse uma "boa" aula.

Todos foram unânimes em dizer que queriam mudar e que havia necessidade de se ter um ambiente favorável ao estudo. Essa opção de mudança, para nós, selava um compromisso a ser assumido. Porém, as sugestões de mudanças sugeridas pelos alunos não atendiam às minhas expectativas enquanto filosofia de ensino. As sugestões dos alunos eram um tanto quanto conservadoras e autoritárias. Eles queriam que o professor fosse "mais rígido", com mais "autoridade" e "maior domínio" sobre a turma, para que os alunos ficassem "mais quietos" e "se preocupassem com o futuro". No entanto, o meu objetivo era o contrário, e dele não abria mão: queria que os alunos assumissem os estudos e a disciplina em sala de aula como uma responsabilidade deles e não do professor.

Chamaram-me muito a atenção as diversas "falas" dos alunos. Em muitas dessas falas eles criticavam o "discurso" escolar - "todo ano se fala nisso e nunca muda". Quer dizer, todo ano se fala que o estudo é importante, fala-se da necessidade do respeito, que temos que ser colegas, mas que na prática parece que nada muda. Decorreria daí o fato de os alunos estarem descrentes da possibilidade de mudanças. Certamente, depois de muitos anos de escolarização, verificaram que a instituição escola não mantém uma coerência entre o dito e o feito. Para a maioria dos alunos, a fala do professor se assemelha a um discurso demagógico, a exemplo de certos políticos. Nesse mesmo sentido, os alunos contestam com veemência todas as formas de generalizações, exigem que o professor veja as especificidades.

Contudo, possuem certa clareza sobre a fase da adolescência e de suas ambiguidades. Na difícil tarefa de construírem suas identidades, deparam-se com dilemas, como o da necessidade de estudarem e, ao mesmo tempo, dos apelos à amizade e à sexualidade. De certa forma, gostariam de estudar conversando, conciliando os sentimentos da amizade com o estudo. Outro dilema que foi objeto de longas discussões foi o de que os adolescentes são responsáveis para votar podendo até escolher o Presidente da República, mas que a sociedade não permite que possam dirigir um automóvel aos dezesseis anos. Reclamavam: a sociedade (Estado, família, escola) exige que sejamos responsáveis, mas eles não cumprem com suas responsabilidades. E o que dizer da indiferença de muitos alunos na busca dos conhecimentos, os alunos desinteressados? De se estudar só pela nota? Muitas vezes, na primeira aula, cheguei a contar dez alunos debruçados em cima da carteira dormindo. Indagados, respondiam com certa revolta dizendo que necessitavam dormir. Alguns tinham sono devido ao trabalho, outros porque ficavam vendo televisão até altas horas da madrugada. 
Os sentimentos dos adolescentes são muito fortes e, às vezes, vão além dos argumentos racionais. Numa aula, um grupo de meninas se negava em participar. Então, sugeri que fossem à biblioteca e fizessem o que lhes agradasse e que ao final da aula nos trouxessem por escrito o que tinham feito. Apresento o relato de uma dessas alunas.

\footnotetext{
"Eu li o "meu” livro, porque eu precisava acabar de ler até o último horário. Eu li o Diário de Um Mago, mas já li, as Valquírias, O Alquimista, Brida, Na Margem do Rio Piedra Eu Sentei e Chorei, O Monte Cinco, e comecei o Maktub. São todos do Paulo Coelho.

Gosto muito dos livros dele, porque tem vários conselhos para ser feliz e aproveitar a vida, tenho o objetivo de ler todos os livros dele, mas não sei se vou conseguir, pois os que haviam na biblioteca do colégio eu já li todos, vou tentar na biblioteca pública.

Eu também gosto da maneira que ele relata os fatos. No último que eu acabei de ler, O Diário de Um Mago, tem vários "rituais", muito simples, que ajudam a afastar maus pensamentos e etc. Os resultados dão certo sem que você perceba.

O senhor já leu algum livro do Paulo Coelho? Qual? Qual é a sua opinião sobre o autor e seus livros? Tem algum para me emprestar? " (Caroline).
}

Infelizmente, enquanto iniciante de professor reflexivo não soube explorar esse interesse das alunas. Limitei-me em responder às questões que me foram propostas dizendo que toda a leitura é importante, mas que devemos selecioná-las e variá-las. Disse que não havia lido nenhum livro de Paulo Coelho, e que esse tipo de leitura não era aconselhável, pois ficava restrito ao misticismo. Comparei Paulo Coelho à música "brega" e indiquei outros autores de nossa literatura. As alunas ficaram em silêncio e um tanto espantadas.

Os adolescentes também revelam uma boa capacidade de compreensão sobre a atuação dos professores quando dizem que "a bagunça dos alunos está relacionada com a insegurança e fraqueza do professor". Em nossas aulas, foi, de certo modo, isso mesmo que aconteceu. Enquanto professor que buscava um ensino reflexivo, havia insegurança e confusão, embora, com a diferença que aquela "confusão" era objeto de reflexão e estudo do professor e dos alunos.

Na tentativa de garantir mudanças significativas na perspectiva de meus anseios, tive a ideia de que teria que "materializar" minhas intenções de mudanças, elaborando uma "breve constituição para a sala de aula". A metodologia e a proposta da constituição foram de iniciativa do professor. Os alunos concordaram. O trabalho foi planejado do seguinte modo: 
1ㅇ) Solicitei aos alunos que escrevessem suas histórias de vida. Para isso criei um ambiente favorável em sala de aula, no qual o professor relatou sua história de vida, dando destaque as suas fraquezas e ao modo como as havia superado desde a infância. A atenção e o interesse dos alunos foram significativos. Em seguida, após os alunos escreverem suas histórias de vida, deveríamos discuti-las em sala de aula e elencarmos alguns pontos em comum. Os alunos resistiram e não aceitaram tal encaminhamento, porque, segundo eles, as histórias de vida traziam questões muito pessoais. Respeitei-os e realizei em casa a síntese que em seguida foi devolvida à turma;

2ㅇ) Fiz uma espécie de investigação, refletindo sobre os valores que fundamentavam as ações dos alunos. Queria que eles refletissem sobre o valor do ser pessoa e de como se respeitar. Os alunos leram a Declaração Universal dos Direitos Humanos e algumas passagens da Bíblia por eles mesmos escoIhidas;

3ํ) Realizamos uma reflexão sobre quais eram seus objetivos enquanto estudantes;

4ㅇ) Por fim, elaboramos algumas normas e punições para regulamentar a nossa convivência.

Não tínhamos clara a forma do texto. O objetivo não era apenas escrever uma "lei", mas escrever sobre nossas falas e o propósito de se assumir um compromisso de mudança com responsabilidade. $\mathrm{O}$ trabalho seguiu esta ordem: reflexões individuais, em grupos e, por fim, apresentação, discussão em plenária e votação.

Todo o material foi recolhido pelo professor que, em casa, redigiu o texto. Não daria para os alunos fazerem este trabalho em sala de aula? Penso que sim. Mais uma vez concentrei o trabalho em minhas mãos, com receio de que fosse muito complicado fazer a sistematização com os alunos. Apenas entreguei o manuscrito a duas alunas voluntárias que o digitaram. A "constituição da sala de aula" teve a seguinte estrutura: introdução, princípios, objetivos, nossas leis, formas de punições (não será possível apresentar seu conteúdo, pelos limites do texto, uma vez que ela tem três páginas).

A elaboração da "constituição" foi uma forma de educar para a cidadania ativa. Os alunos vivenciaram o choque de interesses entre eles e a dificuldade de encontrarem consensos possíveis. Refletiram sobre a importância da lei na garantia de nossos direitos e da necessidade de participação para que isto de fato aconteça. Apesar de alguns alunos ficarem indiferentes e de levarem na brincadeira, a grande maioria se interessou e participou ativamente. As discussões na plenária, com a duração de três semanas, foram exaltadas e expressaram muitas revoltas. Os alunos, em cada ponto, referiam-se a determinados professores, fazendo desabafos contestadores, a revolta era muito grande. A coordenação da plenária, 
escolhida democraticamente entre a turma, a cada aula, ficava a cargo de três alunos que formavam a mesa coordenadora. Em muitos momentos, porém, a mesa perdeu o controle da turma. A dificuldade de coordenar era tanta que, em uma aula, os alunos escolhidos se recusaram em assumir os trabalhos. Eu tinha de fazer intervenções constantes, pois, quando um aluno iniciava uma fala que era de interesse da maioria, quase todos começavam a falar ao mesmo tempo, e levava algum tempo até que eu pudesse contornar a situação. Acertávamos que não era assim, que devíamos seguir as normas do item 1 e 2 da constituição; todos concordavam, porém, assim que surgia um novo ponto conflitivo, todos voltavam a falar ao mesmo tempo, de forma emotiva.

Quando concluímos essas reflexões sobre a "constituição", já estávamos no início do quarto bimestre. Tínhamos que fazer a redação final e a solenidade de assinatura da "constituição". Infelizmente, enquanto professor, não dei conta de fazer a minha parte, isto é, incorporar no texto original as alterações sugeridas pela plenária. Fiz esse trabalho nas férias. As alunas que haviam digitado a primeira versão do texto perderam o arquivo, não o encontraram mais. Mesmo assim, ficou entre a turma certo entendimento sobre como devíamos agir num diálogo reflexivo, pois ficaram com a primeira versão da constituição.

Seguimos em frente em nossos estudos de Psicologia, com outros temas. Os alunos se cansaram da sexualidade. Então, seguindo as necessidades deles, estudamos sobre as transformações no mundo do trabalho e as consequências para os jovens quanto à escolha profissional. Em seguida, ainda estudamos sobre a influência da televisão em nossas vidas.

Embora essas duas temáticas fossem de interesse dos alunos, observei que a maioria ficou indiferente às aulas. Muitos se negavam a fazer qualquer atividade ou até mesmo a falar sobre o assunto. Segundo esses alunos, suas preocupações, naquele momento, concentravam-se nas outras disciplinas, para as quais faltavam notas para passarem de ano e, como já estavam aprovados em Psicologia, a matéria já não interessava mais. Mesmo aqueles alunos que participavam, faziam-no de um modo que em nada lembrava os compromissos assumidos na constituição e do diálogo reflexivo.

Cheguei ao final do ano com a impressão de ter fracassado na tarefa de educar os alunos para o diálogo reflexivo. Os objetivos de minha filosofia da educação pareciam ter se diluído nos comportamentos heterônomos dos alunos. Na minha impressão, eles só agiriam com responsabilidade se fossem monitorados permanentemente, e, talvez, isto fosse próprio da adolescência. A essa altura do ano, estava com muitas dúvidas e incertezas, dentre as quais destaco: teria o foco na aprendizagem - ouvir os alunos - 
comprometido o ensino, caindo, assim, no espontaneísmo? Por que os alunos se comportavam de forma indisciplinada, não respeitando o professor que tinha uma proposta de valorizá-los enquanto sujeitos? Queria que os alunos aprendessem a refletir sobre suas vidas, a partir de temas relacionados, extraídos de suas vivências, a fim de desenvolverem suas personalidades com autonomia e responsabilidade e, no entanto, parecia que o resultado tinha sido o contrário.

Foi com essa impressão de fracasso que concluí o ano letivo. Acrescento aqui mais um dado sobre minhas aulas. Um mês antes do término, a direção do colégio solicitou por escrito aos alunos uma avaliação de todos os professores. Apresento abaixo as colocações dos alunos sobre o meu trabalho. Esclareço que o espaço que eles tinham para escrever sobre cada disciplina era de duas linhas.

\footnotetext{
1을 Nada a reclamar e nem a sugerir, ótimo; é muito calmo; muito 10; não termina o assunto que começa; como ele é um pensador, um filósofo, é bom professor de Psicologia; é ótimo professor, explica bem, não deixa com dúvidas, é só pedir que ele explica tudo; bom, adoramos a matéria e o professor; bom, tiramos muitas dúvidas da vida;

1ㅇ B: É legal, mas o professor não tem assunto certo para tratar e ele não se impõe na sala. Mas, os assuntos são interessantes; o professor é muito inteligente, mas às vezes expõe ideias próprias suas, que alguns alunos não aceitam. A matéria é ótima para o desenvolvimento psicológico do aluno; é muito bom; o professor deveria impor mais educação e respeito; legal, porque sempre fecha o "carroço" (tá ligado); é uma pena que são poucos os alunos que o entendem, mas as aulas são muito interessantes; bom, por causa da matéria; ótimo (gosto de falar e debater sexo na adolescência); ótimo, para quem se interessa; assuntos sem lógica, professor não sabe se expressar, é muito bom, ele é esquisito, não sabe captar ideias; ótimo (3 vezes).
}

Durante as férias, ao retomar os apontamentos das aulas, verifiquei que necessitava ouvir novamente os alunos. A avaliação feita pela direção era restrita e tinha outro objetivo. Precisava confirmar minhas convicções com as falas finais dos alunos. Elaborei, então, quatro questões e retornei ao colégio em 25 de fevereiro de 2000. 1. Por que, em linhas gerais, não conseguimos, enquanto turma, chegar ao final do ano capazes de dialogar disciplinadamente e democraticamente no coletivo, conforme prescrições da nossa constituição por nós mesmos elaborada em sala de aula? (Refletir sobre a dificuldade que a grande maioria tem de manter a coerência entre o pensar, falar e fazer); 2 . Aponte em que sentido o trabalho do professor se diferenciou (se é que houve diferença) do trabalho dos outros professores; 3. Que sugestões vocês dariam ao professor que está tentando construir uma metodologia de ensino reflexivo? 4. O que levamos para nossas vidas das aulas de Psicologia? 
Fui recebido pelos alunos com muita alegria e curiosidade. Muitos lamentaram a minha não continuidade com eles naquele ano. Informei que estava necessitando concluir as aulas de Psicologia do ano anterior, e que, para isto eles teriam de responder as questões propostas. Em grupos, em trinta minutos, prontamente responderam. A seguir, devido aos limites do texto, apresento as respostas das questões dois e quatro.

2. Aponte em que sentido o trabalho do professor se 'diferenciou' (se é que houve diferença) do trabalho dos outros professores?

- Sim, todos deram sugestões e opiniões [...];

- Se diferenciou no fato de ele ouvir e aceitar abertamente a opinião dos alunos, mesmo apesar de às vezes serem ideias sem lógica nenhuma, ele dava um jeito de tirar algum proveito delas;

- Pelo motivo de haver bastantes diálogos [...] para esclarecer dúvidas [...];

- Porque em todas as aulas nós tratávamos de assuntos de nosso interesse [...];

- [...] pensamos, falamos, mas também aprendemos muito;

- O professor nos ouvia, queria saber qual era nossa opinião;

- O professor gostava muito de saber nossas ideias e que tivéssemos nossa opinião própria sobre a aula e sobre o método do professor;

- Em várias aulas o professor trouxe assuntos interessantes, mas como o professor era muito bonzinho, os alunos bagunçavam nas aulas e o professor só mandava eles fazerem alguns trabalhinhos em casa, assim quando tinha um assunto que interessava, todos iam bagunçar com os outros para se aparecer;

- Para mim houve diferença, pois [...] nos ensinou para a vida, ou seja, a refletir;

- Fez com que nossas ideias prevalecessem, ou seja, nos respeitou como adultos, de iguais para iguais, não deixando de ser o professor e, além de tudo, respeitou nossas atitudes e ao invés de reprimi-las, tentou entender o motivo delas acontecerem";

- Sim, houve diferença. O professor era mais calmo e tentava (em meu ver) entender o porque os alunos bagunçavam, ao contrário dos outros que apenas brigavam e influenciavam a nota; - O professor levou nós para fora da sala para discutir o assunto e foi muito bom $[\ldots]$;

- Abordou assuntos importantes e teve um diálogo de debate muito aberto com os alunos;

- Sim, porque nós muitas vezes escolhemos os assuntos para discutirmos;

- Sim, porque o professor trabalhava com o nosso lado psicológico, mudando nossa maneira de pensar, em aulas onde há diálogo entre o grupo mais o professor;

- O professor conversa muito e manda pouco;

- Foram tratados assuntos nunca comentados anteriormente em sala de aula, onde o professor valorizava a opinião de todos, ouvindo e respeitando; foram assuntos polêmicos onde todos de alguma forma participaram;

- O professor tentava atrair a atenção dos alunos com assuntos diferentes e polêmicos, enquanto os outros só chegavam e passavam matéria no quadro;

- Sinceramente o professor era muito calmo, não passando autoridade e assim 
fazendo com que os alunos não tivessem medo";

- Claro que sim, pois é o único professor que demonstrou ser amigo de verdade, fazendo-nos acreditarmos em nós mesmos;

- O professor entendia o sentimento do aluno e tentava ajudá-lo enquanto outros professores complicar mais ainda, deixando o aluno mais confuso ainda;

- No sentido de reflexões e anotações de ideias. Fez os alunos expressarem seus sentimentos. No começo houve conflitos [...].

4. O que levamos para nossas vidas das aulas de Psicologia?

- Levamos muitas coisas boas. No começo parecia ser pobre, mas fomos tendo conhecimento e nos interessou;

- O que aprendemos sobre nós, nosso corpo. Que diante de nossas brigas, a gente aprendeu coisas boas;

- Aprendi a ser um pouco mais compreensiva e menos explosiva, aprendi muito sobre sexo e sobre nós adolescentes. Gostei muito de ter o senhor como meu professor e sinto saudade de suas aulas, das poucas e ótimas conversas que tivemos e de sua compreensão;

- Que o respeito é a base de tudo na vida; [...] Amadurecemos mais, principalmente respeitando as pessoas;

- A refletir sobre nossas atitudes e aprender mais sobre nós mesmos;

- Como agir na sociedade e refletir sobre assuntos nossos;

- Aprendemos a debater temas polêmicos que existem em nossa vida;

- Levamos muitos conhecimentos de todos os assuntos que debatemos, aprendemos a ouvir a opinião dos nossos colegas e também percebemos que cada pessoa tem uma forma diferente de pensar;

- Aprendemos sobre nós mesmos, sobre nossas vidas, assuntos que realmente nos interessam. Esse aprendizado, creio que será muito importante para nós no decorrer de nossas vidas;

- Levamos muitas coisas boas, adquirimos um bom potencial para uma boa convivência num futuro muito próximo e também estamos mais responsáveis pelas coisas que fazemos. Obs.: agradeço por tudo o que me ensinou e que deus o abençoe!;

- Muitos pontos positivos como: o respeito, o essencial para toda a vida, a reflexão, pois tudo deve ser refletido para se fazer bom proveito do assunto; a compreensão de ideias opostas, pois cada ser humano é diferente. Obs.: "não concordo com o que você falou, mas defendo até a morte o direito de você falar";

- Referente ao ano letivo de 1999, ficamos totalmente "expertos" sobre sexo e de como diferenciar o amor da atração sexual e paixão de tesão. Todos os assuntos relacionados (masturbação...), estamos agora mais inteirados e maiores conhecedores de si;

- Em nosso entender, aprendemos como superar nossos conflitos e de como dominá-los para não descontar em cima dos outros;

- [...] Que de tudo somos capazes, que podemos aprender com os outros;

- Tudo. Psicologia é vida [...] Viveremos mais felizes;

- Os assuntos em casa ficaram mais interessantes, pois o que aprendemos nas aulas, passamos em casa. Amadurecemos muito para a nossa vida lá fora, aprendemos a ter um pouco de respeito pelo nosso próximo, aprendemos que a vida não é só feita de brincadeiras e sim de trabalho;

- Adquirimos um autoconhecimento sobre nós mesmos, respeitar e ser respeitado 
em sala de aula, dialogar sem conflito, impor nossas opiniões e, com certeza, todas as coisas que o professor ensinou, não importando o assunto, levaremos para nossa vida inteira. Deixamos de ser adolescentes ingênuos, onde poucos conhecimentos tínhamos e passamos a ser jovens responsáveis e críticos sobre nossos próprios atos. Com a permanência do diálogo na sala, nos empolgamos e perdemos um pouco da vergonha, da timidez, e assim acabamos nos entendendo mais, valorizando e conversando bem mais o dialogo entre nossos pais e familiares. Obs.: Gostaríamos de agradecer ao professor pela colaboração e paciência que teve durante o ano, pela disposição, e por nos ter passado não apenas o aprender, mas também o saber.;

- Que devemos ter mais diálogo, mais amor;

- Um conceito sobre coletividade [...];

- Na nossa vida não mudou muito, mudou mais em sala de aula. Na minha opinião o senhor devia fazer uma palestra para nossos pais.

- A minha vida mudou em sala de aula. A minha reunião [a aluna queria reunir a família em casa para refletirem sobre seus problemas] não deu muito certo, ou melhor, não deu para fazer. Mas tudo bem, apesar que eu gostaria de ter feito. Admiro seu trabalho e sua pessoa apesar de que às vezes as aulas são chatas.

- Costumo ser muito sincera com meus pais. Meu pai parece não gostar de minhas ideias inovadoras. As aulas ajudaram a refletir o respeito do diálogo em família, mas meu pai não gosta de conversar. Estou mais consciente dos meus atos e resolvi estudar este ano, já que quero passar no vestibular numa Faculdade Federal, pois não tenho condições de pagar uma particular. Obrigado, suas aulas me ajudaram a refletir. Desculpe a demora para reconhecer e a falta de respeito que tivemos para com o senhor. Valeu!!!

- Acho que minha vida melhorou um pouco, mas não muito, principalmente com meus pais. Apesar disso acho que ainda vai melhorar, graças as aulas de psicologia.

Essas falas dos alunos, na oportunidade, sinalizaram para mim que o objetivo da formação de sujeitos com autonomia moral e autodisciplina intelectual, em parte, tinha sido alcançado.

\section{Considerações Finais}

Penso que errei na avaliação precipitada sobre os alunos, ao considerá-los incapazes de dialogar reflexivamente, sem responsabilidade. $O$ trabalho revelou que as aprendizagens, principalmente quando se trata da formação da pessoa (ser) e da convivência, necessitam de um tempo razoável para se consolidarem. Nesse sentindo, o educar é um processo dialético de permanente construção.

Tive uma concepção muito "idealista", querendo que os alunos se enquadrassem num modelo que tinha idealizado. As aulas são um processo contraditório e confuso, tem momentos de avanços e de retrocessos, nos quais o professor precisa desenvolver a "dimensão artística” de que falava Saviani. Está aí o desafio da originalidade e da criação. Porém, entendo que essa dimensão artística do ensino não pode 
ser reduzida somente ao "conhecimento tácito" tal como propõe a teoria do ensino reflexivo. Ao contrário, a dimensão artística da docência somente pode avançar quando o docente tem uma sólida formação teórico-metodológica na perspectiva de conhecimento dos fundamentos das ciências, da filosofia e da política. Mudança em educação, como nos ensinou Florestan Fernandes (2010) no clássico artigo “A formação política e o trabalho do professor", é sempre mudança política. Assim

A disjunção da pedagogia ou da filosofia e das ciências ou da arte, com relação à política, seria um meio suicida de reagir. É algo inconcebível e é retrógrado. $\mathrm{O}$ professor precisa se colocar na situação de um cidadão de uma sociedade capitalista subdesenvolvida e com problemas especiais e, nesse quadro, reconhecer que tem um amplo conjunto de potencialidades, que só poderão ser dinamizadas se ele agir politicamente, se conjugar uma prática pedagógica eficiente a uma ação política da mesma qualidade (FERNANDES apud OLIVEIRA, 2010, p. 135).

O trabalho com aquelas duas turmas certamente teria sido diferente, se as condições de trabalho fossem outras. Precisaria da participação de todos os professores da turma e da direção do colégio, o que não foi feito por duas razões: primeiro, por eu ser iniciante e, de certo modo, inseguro sobre a prática de um ensino reflexivo. Segundo, pelas próprias condições de nosso trabalho, extensa jornada e, também, pela própria estrutura de funcionamento do colégio que é a expressão da política educacional da Secretaria de Estado e Educação, a qual não possibilita espaço em horário de trabalho, para que os professores possam se reunir em grupos para refletirem sobre seus trabalhos.

Outro ponto que me chamou a atenção foi o comportamento de muitos alunos. Um comportamento agressivo, de revolta, desordenado, enfim, de indiferença. Enquanto professor, senti esse desrespeito. Apesar de minha filosofia de educação ser democrática, livre e de acolhimento aos alunos, além de eles mesmos, em certos momentos, escolherem os temas a serem estudados, mesmo assim, não éramos respeitados. Por exemplo, ao entrar em sala de aula, a turma permanecia indiferente a minha presença, continuando com as conversas e andando pela sala. Ao refletir sobre o motivo de isso acontecer, o argumento era quase sempre o mesmo: necessidade de conversar sobre os relacionamentos, amizades, novelas, futebol, lazer, música etc.

Ao trazer esses assuntos para reflexão e estudo gerava uma espécie de desconforto e resistência nos alunos. A conversa, para eles, tinha de ser informal e não ser transformada em objeto de reflexão. Enfim, até criar um ambiente favorável ao estudo em sala de aula, passava-se um bom tempo e, às vezes, toda a aula (duração de uma aula: 45 minutos). Em muitos casos, depois de tudo acertado para iniciar uma 
atividade, alguns alunos retornavam a conversar. Então chamava a atenção pelo desrespeito ao encaminhamento coletivo e democrático, e esses alunos ridicularizavam minha fala, dando de ombros e debruçando-se sobre a carteira e ironizando com palavras de deboche. A impressão que tive é de que esses alunos, com esse comportamento, queriam de certa forma, talvez, dizer: estudar para quê? Refletir para quê? Pareceu-me um vazio em que nada valia a pena.

Mesmo entre eles, os alunos, as relações pareciam ser entre "coisas" e não entre pessoas que pensam e têm uma dignidade. As relações eram harmônicas no interior de cada grupo, mas extremamente conflitantes e excludentes entre os grupos. O outro era visto como alguém que precisasse ser diminuído e, às vezes, até destruído, para a própria afirmação. Surpreendia-me que numa das turmas, na primeira aula do dia, uma aluna e sempre ela, fazia uma oração inicial. Essa oração era uma reflexão dirigida a Deus e concluída muitas vezes com a oração do "Pai Nosso". A turma toda se concentrava e rezava com seriedade. Estavam no "céu". Concluída a oração, começava o desrespeito e a negação do outro. Estavam na "terra". E aqui na "terra" era como se estivessem num outro mundo em que a oração praticamente nada valia. Enfim, busquei, mediante reflexões, mostrar-Ihes que o "Deus" em que acreditavam era "metafísico" e que assim não havia sentido rezar. Que era preciso ver "Deus" no colega e na vida dos homens. Fui pouco compreendido ou talvez não tenha conseguido me fazer compreender, pois a forma de pensar dos alunos era extremamente dogmática e, por consequência, fechada.

Havia na sala um descontrole de bate-boca, gritos, enfim, pareceu-me ser uma fala guiada pelo instinto emotivo e não pela razão ${ }^{3}$, que me provocou enorme desgaste físico, emocional, de voz e também intelectual. Na própria aula, nos momentos de maior conflito, tive dificuldade para organizar meus pensamentos, pois a "pressão psicológica" dos alunos era intensa.

Disso decorreu a dificuldade do professor em fazer as mediações e retomar essas falas instintivas como objeto de reflexão. Às vezes, essa retomada irritava os alunos, pois não concordavam em refletir sobre o que consideravam de certa forma normal. Como trabalhava também no ensino superior, cheguei a dizer que preferia trabalhar dez aulas na Universidade a uma aula no Colégio. O registro das falas, as situações imprevistas, as contradições, enfim, o conhecimento sobre a vida dos alunos e de como trabalhar

\footnotetext{
${ }^{3}$ Aristóteles (1991) observa que os jovens agem mais pela paixão do que pela razão. Diz “[...] um jovem não é bom ouvinte de preleções sobre a ciência política. Com efeito, ele não tem experiência dos fatos da vida, e é em torno destes que giram nossas discussões; além disso, como tende a seguir suas paixões, tal estudo lhe será vão e improfícuo, pois o fim que se tem em vista não é o conhecimento, mas a ação. [...] A tais pessoas, como aos incontinentes, a ciência não traz proveito algum; mas aos que desejam e agem de acordo com um princípio racional o conhecimento desses assuntos fará grande vantagem" (1991, p. 10).
} 
com as diferenças, requerem do professor muito tempo de análise, reflexões, busca de materiais e, sobretudo, de diálogo com seus colegas, para a busca de soluções conjuntas a cada semana.

No meu caso, não dei conta, por exemplo, de trabalhar com mais profundidade as "histórias de vida" dos alunos, explorar melhor aquelas falas. Também não dei conta de planejar para que os alunos sistematizassem suas falas, como foi no caso da sistematização da constituição da sala de aula. Por tudo isso, para o professor desenvolver um "ensino reflexivo" ou ser um "professor pesquisador", rompendo assim com a alienação da profissão, fazem-se necessárias condições dignas de trabalho, com redução significativa da carga horária semanal em sala de aula e de melhorias salariais.

\section{Referências}

ARISTÓTELES. Ética a Nicômaco. 4. ed. São Paulo: Nova Cultural, 1991. (Os Pensadores; v. 2).

DEWEY, J. Como pensamos. 2. ed. São Paulo: Ed. Nacional, 1953.

FERNANDES, F. A formação política e o trabalho do professor. In: OLIVEIRA, M. M. (Org.), Florestan Fernandes. Recife: Fundação Joaquim Nabuco, Editora Massangana, 2010. p. 119-140.

GOMES, A. P. O pensamento prático do professor: a formação do professor como profissional reflexivo. In: Nóvoa, António (Coord.). Os professores e a sua formação. 2. ed. Lisboa: Publicação Dom Quixote, 1995. p. 93-114.

GRAMSCl, A. Os intelectuais e a organização da cultura. 8. ed. Rio de Janeiro: Civilização Brasileira, 1991. GRAMSCI, A. Cartas do Cárcere. Vol. 1. Rio de Janeiro: Civilização Brasileira, 1999.

GRAMSCl, A. Cadernos do cárcere. Vol. 2. Rio de Janeiro: Civilização Brasileira, 2000.

KONDER, L. O futuro da filosofia da práxis: o pensamento de Marx no século XXI. Rio de Janeiro: Paz e Terra, 1992.

MANACORDA, M. A. O princípio educativo em Gramsci. Porto Alegre: Artes Médicas, 1990.

NÓVOA, A. Os professores e sua formação. 2. ed. Lisboa: Portugal: Dom Quixote, 1995.

SAVIANI, D. Escola e democracia: teorias da educação, curvatura da vara, onze teses sobre educação e política. Campinas: Autores Associados, 1997.

SAVIANI, D. Pedagogia Histórico-Crítica. 8. ed. Campinas: Autores Associados, 2003.

SAVIANI, D. Antecedentes, origem e desenvolvimento da Pedagogia Histórico-Crítica. In: MARSIGLIA, A. C. G. (Org.), Pedagogia Histórico-Crítica: 30 anos. Campinas, SP: Autores Associados, 2011.

SCHÖN, D. Formar professores como profissionais reflexivos. In: Nóvoa, António. Os professores e a sua formação. 2. ed. Lisboa: Dom Quixote, 1995. p. 77-92.

ZEICHNER, K. M. A formação reflexiva dos professores: ideias e práticas. Lisboa: Dom Quixote, 1993.

Recebido em agosto de 2016. Aprovado em outubro de 2016. 